\title{
Dietary water seems to improve skin hydration without influencing hemodynamics
}

\author{
A água da dieta parece favorecer a hidratação cutânea sem afectar a hemodinâmica.
}

\author{
Federica Tomasino ${ }^{1,2}$ Maria Lídia Palma ${ }^{2}$, Carla Monteiro², Liliana Tavares ${ }^{2}$, Julia Bujan ${ }^{3}$ \& \\ L. Monteiro Rodrigues ${ }^{2,4}$ \\ ${ }^{1}$ Università degli Studi di Palermo, School of Pharmacy, Dip. Scienze Tecnol. Biol. Chimihe e Farmaceutiche, \\ Viale delle Scienze Ed., 16, 90128 Palermo, Italia \\ ${ }^{2}$ Universidade Lusófona (CBIOS - Research Center for Health Science and Technologies), Campo Grande, 376, \\ 1749-024, Lisboa, Portugal \\ ${ }^{3}$ Universitad de Alcalá Henares, Faculty of Medicine, Madrid, Spain \\ ${ }^{4}$ Universidade de Lisboa (Faculty of Pharmacy)- Dep. Pharmacological Sciences \\ Email: p1814@ulusofona.pt; lidia.palma@ulusofona.pt
}

\begin{abstract}
The various studies on the importance of water in the hydration of human skin have suggested that an increased dietary intake might positively impact the physiology of normal skin. We evaluated the consequences of increasing water intake through drinking in skin hydration in vivo. Eating habits were maintained, evaluated by a Food Frequency Questionnaire and based on total water consumption. In two groups with different total water consumption, we evaluated the impact of $2 \mathrm{~L} /$ day water after 30 days,. This increase produced no hemodynamic changes or weight changes but an improvement in the epidermal hydration was suggested. The magnitude of the impact on skin hydration was higher in the group that regularly consumed less water, suggesting that the increase in water consumption has more beneficial effects on those individuals who habitually consume less water per day. These data are consistent with the published literature, justifying interest in looking further into this topic, in order to better understand the importance of dietary water in the context of cutaneous physiology, especially in the group of subjects with reduced consumption habits.
\end{abstract}

Keywords: dietary water; skin hydration; bioimpedance; in vivo.

\begin{abstract}
Resumo
Os vários estudos sobre a importância da água na hidratação da pele humana vêm sugerindo que o aumento da ingestão de água pode ter um impacto positivo na fisiologia da pele normal. Mantendo os hábitos dietários, avaliados por Questionário de Frequência Alimentar e com base no consumo de água total, avaliámos as consequências do aumento de água bebida na bioimpedância e na hidratação da pele "in vivo". Em dois grupos com diferentes consumos de água total, avaliamos, ao fim de um mês, o impacto do aumento do aporte de $2 \mathrm{~L} /$ dia de água bebida. Este aumento não produziu alterações hemodinânicas ou ponderais. Os resultados sugerem uma melhoria da hidratação epidérmica. A magnitude do impacto sobre a hidratação cutânea é maior no grupo que regularmente consome menos água, sugerindo que o aumento do consumo de água tem mais efeitos benéficos na saúde cutânea dos indivíduos que consomem menos água por dia. Estes dados estão de acordo, com a literatura publicada, justificando o interesse no aprofundamento do tema, de modo a contribuir para o conhecimento sobre a importância da água no contexto da fisiologia cutânea em especial no grupo de indivíduos com hábitos de menor consumo.
\end{abstract}

Palavras-chave: Água da dieta; Hidratação cutânea; bioimpedância; in vivo. 


\section{Introduction}

Water is the main component of organs, tissues and cells ${ }^{[1]}$ and therefore the functioning of the human body critically depends on this nutrient as it is vital for all body functions. Water participates in all physiological processes of digestion and absorption, acts as a transport system for nutrients, helps to eliminate nondigestible metabolic waste, serves as a lubricant, and plays a role in the maintenance of body temperature ${ }^{[2,3]}$. The water required for normal physiological processes comes from the metabolism of macronutrients (carbohydrates, proteins, lipids) from food and especially from fluid intake (water consumed by one's own will or determined by the thirst reflex). The body regulates the water balance independently through the hypothalamus, maintaining the required amount of water in order to prevent dehydration and to maintain a constant balance between water intake and elimination (urine, breath, feces and skin) ${ }^{[4,5]}$.

Water is an essential nutrient, but there is no clear definition regarding daily requirements ${ }^{[6]}$. It is only possible to define a value of "adequate" water consumption sufficient to maintain normal hydration, which is dependent on the climatic conditions where one lives, on physical activity and on personal metabolism, which are different for each individual $\mathrm{l}^{[7]}$.

With respect to the importance of water in the skin, the water content of the stratum corneum (SC) is a major determinant regulating its function, as with other keratinized tissues ${ }^{[8]}$. Water affects the permeability and flexibility of SC and modulates the activity of various enzymes involved in the processes of formation and scaling of the skin barrier ${ }^{[9]}$.

Considering that measurement of water consumption depends on its various origins, the 2010 study of the consumption pattern in the Portuguese population identified how the various types of water intake contributed to the total amount of water consumed (drunk water, water from food, and water contained in drinks). A food frequency questionnaire (FFQ) was used as a measuring instrument through which it was possible to measure the total water intake of the studied population as the sum of the drunk water $(\mathrm{AgB})$, water from the $\operatorname{diet}(\mathrm{AgD})$ and metabolic water. In doing so, it was possible to measure the contribution of the various components to the total water supply ${ }^{[10]}$. Based on the total water intake, we tried to assess the impact that an additional intake of water in the diet would have on skin hydration in vivo, without changing other aspects of daily eating habits.

\section{Introdução}

A água constitui o principal componente de órgãos, tecidos e células ${ }^{[1]}$, pelo que, o funcionamento do corpo humano está, criticamente, dependente da água, encarada como um nutriente que assegura as funções vitais do organismo. A água participa a todos os processos fisiológicos de digestão e absorção, actua como sistema de transporte de nutrientes e na eliminação de resíduos metabólicos não digeríveis, funciona como lubrificante e desempenha um papel na manutenção da temperatura corporal ${ }^{[2,3]}$.

A quantidade de água necessária para o funcionamento normal dos processos fisiológicos provem da metabolização dos macronutrientes (carbohidratos, proteínas, lípidos), dos alimentos e principalmente da ingestão de líquidos (agua bebida por vontade própria o por reflexo da sede). O organismo regula o balanço hídrico de modo autónomo através do hipotálamo mantendo a quantidade de água necessária para evitar a desidratação e mantendo um equilíbrio constante entre a água ingerida e a água eliminada (urina, respiração, fezes e pele) ${ }^{[4,5]}$.

Sendo a água um nutriente fundamental, não existe, contudo para a água uma definição clara sobre as necessidades diárias ${ }^{[6]}$. Só é possível definir um valor "adequado" do consumo de água suficiente para manter uma hidratação normal, facto que, depende das condições climáticas em que cada um vive, da actividade física e do metabolismo pessoal que são diferentes para cada individuo ${ }^{[7]}$.

Reconhecida que é a importância da água na pele, o teor em água do estrato córneo (EC) é o mais importante factor de regulação da sua função e de outros tecidos queratinizados $^{[8]}$. A água afecta a permeabilidade e a flexibilidade do EC e modula a actividade de várias enzimas envolvidas nos processos de formação e dimensionamento da barreira cutânea ${ }^{[9]}$.

Considerando que a contabilização da agua consumida deve atender as suas varias origens, o estudo sobre o padrão de consumo na população portuguesa em 2010 permitiu identificar o contributo dos vários aportes na quantidade total de água consumida (água bebida, água dos alimentos, água contida nas bebidas), utilizando como instrumento de medida um inquérito de frequência alimentar (QFA), através do qual foi possível contabilizar o aporte total de água da população em estudo como o somatório da água bebida (AgB), água da dieta $(\mathrm{AgD})$ e água metabólica e, o contributo das várias componentes no aporte total ${ }^{[10]}$. Com base no aporte total de água, procurámos avaliar o impacto que o aporte dietário de uma quantidade adicional de água diária tem sobre a hidratação cutânea "in vivo", sem alterar os hábitos alimentares quotidianos. 


\section{Materials and Methods}

All procedures and methodologies were previously submitted and approved by the Institutional Ethics Committee, ensuring the general principles of good clinical practice applicable to studies involving human volunteers and the full compliance with all ethical standards laid down in the Declaration of Helsinki and subsequent amendments ${ }^{[11,12]}$. All subjects were informed in detail about the study objectives and phases, and expressed their written informed consent. 25 healthy female volunteers, aged between 20 and 37 $(23,72 \pm 4,75)$ years old and without any pathologies or addictions, were selected,. The subjects involved represent an extremely varied sample regarding age, diet and the daily amount of consumed water. This variability is essential in ensuring that the target population is represented. We considered the volunteers' dietary habits of water consumption through a food frequency questionnaire (FFQ) $)^{[13]}$ developed in the Department of Hygiene and Epidemiology, Faculty of Medicine, University of Porto (FMUP). For the conversion of food into nutrients, the software Food Processor Plus ${ }^{\circledR}$, version 5.0 (ESHA Research, USA) was applied. This uses the food composition of the U.S. Department of Agriculture and includes raw and processed foods. The nutritional content of Portuguese foods was added to this database.

Participating volunteers were grouped according to their level of water consumption, which included the sum of drunk water $(\mathrm{AgB})$ as water consumed between meals (water, tea and infusions), water from $\operatorname{diet}(\mathrm{AgD})$ measured through the FFQ and which included water from foods, juices and soup, and water metabolized by the oxidative pathways of macronutrients ${ }^{[14]}$.

The study took place between April and June of last year and lasted four weeks for each volunteer. Three measurements were performed: $\mathrm{T} 0$ at the beginning of the study, T1 after 15 days and T2 after 30 days at the end of the study. Five anatomical areas were selected: forehead, cheekbone, hand (dorsal), forearm (ventral) and leg (dorsal). The anatomical locations were previously marked to ensure measurements were taken in the same anatomical sites. Experimental procedures and techniques did not involve any significant risk or discomfort for patients. These are non-invasive techniques, widely tested and used in the study of human skin function in vivo. During the study, volunteers pledged to maintain their daily dietary and hygiene habits except on measurement days when clear restrictions regarding the use of hygiene products and body care must be observed.

Based on the analysis of total water content in the diet in T0 and using cluster analysis, two groups were constructed: group $1(\mathrm{n}=17)$, with an average total

\section{Materiais e Métodos}

Todos os procedimentos e metodologias aplicadas foram, previamente, submetidas e aprovadas pela Comissão de Ética institucional, garantindo os princípios gerais das boas práticas clínicas aplicáveis aos estudos envolvendo voluntários humanos e o pleno cumprimento de todas as normas éticas previstas na Declaração de Helsínquia e emendas subsequentes ${ }^{[11,12]}$. Todas as voluntárias foram informadas de forma detalhada sobre os objectivos e etapas do estudo, tendo expresso, por escrito, o seu consentimento informado.

Foram seleccionadas 25 voluntárias do género feminino saudáveis, sem patologias ou qualquer tipo de adicção com idades compreendidas entre os 20 e $37(23,72 \pm$ $4,75)$ anos. As voluntárias incluídas constituem uma amostra extremamente variada no que respeita à idade, aos regimes alimentares e a quantidade de água consumida diariamente. Esta variabilidade é essencial para garantir a representatividade da população-alvo. Foram considerados os hábitos dietários de consumo de água dos voluntários através de questionário de frequência alimentar (QFA) ${ }^{[13]}$ e inquérito de consumo diário de água $\mathrm{O}$ QFA utilizado foi desenvolvido no Serviço de Higiene e Epidemiologia da Faculdade de Medicina da Universidade do Porto (FMUP). Para a conversão dos alimentos em nutrientes foi utilizado o programa Food Processor Plus ${ }^{\circledR}$, versão 5.0 (ESHA Research, USA), que utiliza a composição de alimentos do Departamento de Agricultura dos EUA e inclui alimentos crus e processados. A esta base de dados foram acrescentados os conteúdos nutricionais de alimentos portugueses.

As voluntárias que participaram no estudo foram seleccionadas de acordo com a contabilização do consumo total de agua, que inclui o somatório da água bebida $(\mathrm{AgB})$ como a água consumida fora das refeições (agua, chá e infusões), da água da dieta (AgD) contabilizada via QFA e que incluí a água dos alimentos, sumos e sopa e a água metabolizada através da via oxidativa dos macronutrientes ${ }^{[14]}$.

O estudo decorreu entre de Abril e Junho de 2012, e teve duração de 4 semanas para cada voluntária. Foram feitas 3 medições: T0 no início do estudo,T1- após 15 dias e T2após 30 dias no final do estudo. Foram seleccionadas cinco zonas anatómicas: fronte, zigomática, mão (dorsal), antebraço (ventral) e perna (dorsal). As zonas anatómicas foram marcadas para garantir a realização das medidas no mesmo local na zona anatómica em estudo. As técnicas e procedimentos experimentais não ofereciam qualquer tipo de risco ou desconforto relevantes para os pacientes. Trata-se de técnicas não invasivas, amplamente testadas e utilizadas no estudo da função cutânea humana, "in vivo". Durante o estudo as voluntárias comprometeram-se a manter o seu padrão alimentar e os seus hábitos de administração tópica de produtos de higiene e cuidados 
water consumption of $1827.8 \pm 366.13 \mathrm{ml} /$ day and group $2(\mathrm{n}=8)$ with an average water consumption of $3145.7 \pm 424.12 \mathrm{ml} /$ day (Table 1). Given the value indicated by $\mathrm{EFSA}^{[15]}$ as the amount of water suitable for women, all volunteers were asked to drink $2 \mathrm{~L} /$ day of bottled water (mineral water Vitalis ${ }^{\circledR}$ Unicer SA) over the following 30 days. All measurements were made in the laboratory, with continuous monitoring of ambient humidity and temperature according to standard recommendations for this type of study (temperature between 20 and $22^{\circ} \mathrm{C}$, Humidity 40 to $60 \%$ ). Volunteers were given about 15 minutes to acclimatize to the laboratory conditions. All volunteers had a normal ${ }^{[16]}$ Body Mass Index (BMI) value (between 21.99 and $23.28 \mathrm{~kg} / \mathrm{m}^{2}$ ).

The equipment used to measure the influence of the variation of input dietary water on skin physiology and the variables considered were: Bodystat QuadScan ${ }^{\circledR}$ 4000 to evaluate the BMI and the volumes of water distribution in the body, Tewameter ${ }^{\circledR}$ TM 300 (CK Electronics, Germany) for the measurement of transepidermal water loss (TEWL), the MoistureMeterSC (Delfin Technologies, Finland) for measuring the superficial hydration probe $2 \mathrm{~mm}$, the MoistureMeterD (Delfin Technologies, Finland) for measuring the deep hydration probe $55 \mathrm{~mm}$, and the esfingomanometer Mobil Tensoval Hartmann ${ }^{\circledR}$ to measure blood pressure and heart rate. corporais nas áreas anatómicas em estudo incluindo a restrição de aplicação de produtos de higiene e cuidados corporais nos dias das medições.

Com base na análise dos conteúdos em água total das dietas em T0 e utilizando a análise de clusters foram construídos dois grupos; o grupo $1(\mathrm{n}=17)$, com um consumo médio de água total de $1827,8 \pm 366,13 \mathrm{ml} /$ dia e o grupo $2(\mathrm{n}=8)$, com um consumo médio de água de 3145,7 $\pm 424,12 \mathrm{ml} /$ dia (Tabela 1). Atendendo ao valor indicado pela EFSA ${ }^{[15]}$ como a quantidade de adequada de água para as mulheres, foi pedido a todas as voluntárias para beberem diariamente durante 30 dias $2 \mathrm{~L} /$ dia $(2000 \mathrm{ml})$ de água engarrafada (água mineral Vitalis ${ }^{\circledR}$ da Unicer S.A.). Todas as medições foram efectuadas em laboratório, com controlo permanente da humidade e da temperatura de acordo com as recomendações habituais para este tipo de estudos (Temperatura entre 20 e $22{ }^{\circ} \mathrm{C}$ Humidade entre 40 e $60 \%$ ) antes da medição foi assegurada a aclimatação das voluntarias ao ambiente do laboratorial, mantendo-se em repouso cerca de 15 minutos. Todas as voluntárias apresentaram um Índice de Massa Corporal (IMC) normal $^{[16]}$ (entre 21,99 e $23,28 \mathrm{Kg} / \mathrm{m}^{2}$ ). Os aparelhos utilizados para medir a influência da variação do aporte dietário da água sobre a fisiologia cutânea e as variáveis consideradas foram: Bodystat ${ }^{\circledR}$ QuadScan 4000 para avaliação do IMC e Volumes de distribuição de água no organismo, o Tewameter ${ }^{\circledR}$ TM 300 (CK Electronics, Alemanha) para a medida da Perda Transepidérmica de água PTEA, o MoistureMeterSC (Delfin Technologies, Finlândia) para medição da hidratação superficial sonda 2mm, o MoistureMeterD (Delfin Technologies, Finlândia) para a medição da hidratação profunda sonda $55 \mathrm{~mm}$; e o esfingnomanometro Tensoval Mobil Hartmann ${ }^{\circledR}$ para medir a pressão arterial e a frequência cardíaca.

Table 1 - Descriptive analysis of the total water consumption ( $\mathrm{ml}$ ) in the studied population.

Tabela 1 - Análise descritiva do consumo de água total $(\mathrm{em} \mathrm{ml})$ na população em estudo.

\begin{tabular}{lccccc}
\hline & N & Min & Max & Mean/Média & SD/DP \\
\cline { 2 - 6 } Grupo/Group 1 & 17 & 1240,05 & 2211,97 & 1827,8576 & 366,13464 \\
\hline Grupo/Group 2 & 8 & 2571,27 & 3667,11 & 3145,6975 & 424,12377 \\
\hline
\end{tabular}

\section{Bodystat ${ }^{\circledR}$ QuadScan 4000}

The Bodystat QuadScan 4000 ® unit (Bodystat, Isle of Man, UK) was used to perform the Bio-impedance analysis. It operates at various frequencies where Total Body Water (TBW) was calculated at $200 \mathrm{kHz}$ and Extracellular Water $(\mathrm{ECW})$ calculated at $5 \mathrm{kHz}^{[17]}$. The Intracellular Water (ICW) values were indirectly obtained, by calculating the difference between TBW

\section{Bodystat ${ }^{\circledR}$ QuadScan 4000}

O equipamento Bodystat ${ }^{\circledR}$ QuadScan 4000 (Bodystat Isle of Man, UK) opera em várias frequências, sendo os valores de Água Corporal Total (TBW Total Body Water) calculados a $200 \mathrm{kHz}$ e os de Água no Compartimento Extracelular (ECW Extracellular Water) calculados a $5 \mathrm{kHz}^{[17]}$. Os valores de Água no Compartimento Intracelular (ICW Intracellular Water) 
and ECW values. The device uses a regression equation adapted to the equipment. It also calculates BMI. Specific requirements before each measurement were: no food or drink in the six hours before the measurements; restraint from exercising in the twelve hours before the measurements; and no consumption of alcohol or caffeinated drinks in the 24 hours before measurements.

The biometric measurements were made by placing electrodes on the right upper limb (one immediately below the proximal phalanges, another under the radiocubital joint) and in the left lower limb (one immediately below the proximal phalanges, the other in the ankle joint) in dorsal decubitus position (Figure 1), according to manufacturer's specifications. This parameter was analyzed at $\mathrm{T} 0$ and $\mathrm{T} 2$. são obtidos indirectamente, pela diferença entre os valores obtidos de TBW e ECW. O aparelho utiliza uma equação regressiva adaptada ao equipamento. O aparelho calcula ainda o BMI. Foram consideradas como condições antes de cada medição, não ter comido ou bebido nas seis horas anteriores às medições, não ter feito exercício físico nas doze horas que precederam as medições, não ter ingerido bebidas alcoólicas ou cafeinadas nas vinte e quatro horas que antecederam as medições.

As medições biométricas foram efectuadas colocando os eléctrodos no membro superior direito (um imediatamente inferior às falanges proximais, outro sob a articulação radiocubital) e no membro inferior esquerdo (um imediatamente inferior às falanges proximais, outro sob a articulação talocrural), na posição de decúbito dorsal (Figura 1), de acordo com as especificações do fabricante. Este parâmetro foi analisado apenas em T0 eT2.
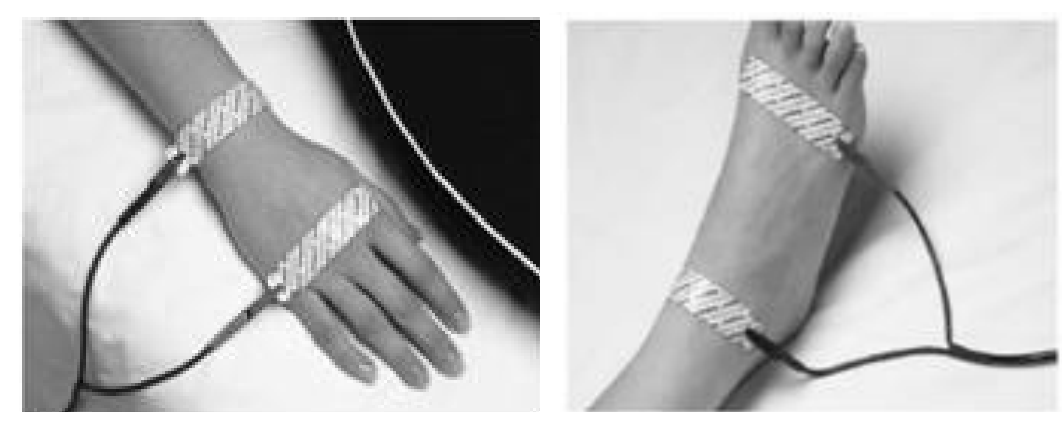

Figure 1 - Ilustration of the positioning of the electrodes used by the system Bodystat ${ }^{\circledR}$ QuadScan 4000.

Figura 1 - Ilustração do posicionamento dos eléctrodos utilizados pelo sistema Bodystat ${ }^{\circledR}$ QuadScan 4000

\section{Tewameter ${ }^{\circledR}$ TM300}

Transepidermal Water Loss TEWL, considered as a reliable indicator of the epidermal "barrier" function was evaluated by the Tewameter TM $300 \AA$ unit (Courage + Khazaka electronic GmbH (Cologne, Germany). Measurements were performed on volunteers by putting the probe head (hollow cylinder, narrow $10 \mathrm{~mm}$ diameter and $20 \mathrm{~mm}$ height) perpendicular to the skin (in the precise measurement site) until an acoustic signal indicates a stable TEWL (this value is set depending on the tolerance limit for the standard deviation). The TEWL value is then analyzed by the microprocessor and, based on the

\section{Tewameter ${ }^{\circledR}$ TM 300}

A Perda Transepidérmica de Água (PTEA) considerada como um indicador da função de "barreira" cutânea, foi avaliada através do sistema Tewameter ${ }^{\circledR}$ TM 300 (Courage+Khazaka electronic GmbH (Köln, Alemanha)

As medições foram executadas colocando a sonda (cilindro oco, estreito $10 \mathrm{~mm}$ de diâmetro e $20 \mathrm{~mm}$ de altura) perpendicularmente sobre a pele (no sitio exacto da medição) até que um sinal sonoro indicasse um valor estável de PTEA, (este valor é estabelecido dependendo do limite de tolerância para o desvio padrão). Este valor é então analisado pelo 
gradients of resulting moisture and temperature, is automatically calculated and shown on the display (unit) $\mathrm{g} / \mathrm{h} \mathrm{m}^{2}$ with the standard deviation detected by a pair of sensors in the probe ${ }^{[18]}$. This parameter was analyzed at $\mathrm{T} 0, \mathrm{~T} 1, \mathrm{~T} 2$.

\section{MoistureMeterSC®}

The MoistureMeterSC $®$ (Delfin Technologies Ltd., Kuopio, Finland) was used to measure the superficial hydration of SC. The MoistureMeterSC ${ }^{\circledR}$ probe, designed to measure the capacitance of the skin at low frequency $(1.3 \mathrm{MHz})$, consists of a measuring unit and a probe with a diameter of $4.5 \mathrm{~mm}$ with a depth measurement that lies above $30 \mu \mathrm{m}$. The probe is equipped with a force sensor (FSG-15NIA Honeywell, Honeywell Mornstown, NJ) to measure the pressure of the probe against the skin. During measurements, four diodes (LEDs) indicate various levels of contact pressure and allow for the selection of a suitable pressure range for each application. The contact force registered corresponds to a force N 1,37-2.06 (two LEDs). Each measurement is started automatically when the probe is placed in direct contact with the skin and perpendicular to the surface of the skin with a constant pressure for few seconds. For each participant, three consecutive measurements were made and the mean of the values was obtained. Superficial hydration was quantified in the T0, T1 and $\mathrm{T} 2$.

\section{MoistureMeterD®}

The MoistureMeterD ${ }^{\circledR}$ (Delfin Technologies Ltd., Kuopio, Finland) was used to measure the deep hydration of the skin. The device consists of a measuring unit and various probes, which are selected according to the desired measuring depth $(0 ; 5-5 \mathrm{~mm})$. The device generates a frequency of $300 \mathrm{MHz}$, sending a low power electromagnetic wave to the coaxial probe and thus to the skin. The electromagnetic wave reflected is recorded, corresponding the reading obtained to the dielectric constant, this being directly proportional to the water content of the tissue measured. A $55 \mathrm{~mm}$ probe was used to measure the amount of water level in the dermis to a depth of $5 \mathrm{~mm}$. Each measurement is started automatically when the probe is placed in direct contact with the skin and perpendicular to the surface of the skin with a constant pressure for a few seconds. For each participant, three consecutive measurements were made and evaluated at T0, T1 and T2. The device shows the measured values directly on the screen. microprocessador e, com base dos gradientes de humidade e de temperatura resultantes, é calculado automaticamente e mostrado no visor em (unidade) $\mathrm{g} / \mathrm{h} \cdot \mathrm{m}^{2}$ junto ao desvio padrão detectado pelos pares de sensores na sonda ${ }^{[18]}$. Este parâmetro foi analisado em $\mathrm{T} 0, \mathrm{~T} 1, \mathrm{~T} 2$.

\section{MoistureMeterSC ${ }^{\circledR}$}

O MoistureMeterSC ${ }^{\circledR}$ (Delfin Technologies Ltd., Kuopio, Finlândia) foi utilizado para medir a hidratação superficial do EC. Concebido para medir a capacitância da pele a baixa frequência $(1,3 \mathrm{MHz})$ é constituído por uma unidade de medição e uma sonda com um diâmetro de $4,5 \mathrm{~mm}$, com uma profundidade de medição que se situa acima dos $30 \mu \mathrm{m}$. A sonda é equipada com um sensor de força (Honeywell FSG15NIA, Honeywell, Mornstown, NJ, EUA) para medir a pressão da sonda contra a pele. Durante as medições, quatro díodos (LEDs) indicam os vários níveis de pressões de contacto e permitem seleccionar a gama adequada de pressão para cada aplicação. A força de contacto registrada corresponde a uma força de 1,37 $2.06 \mathrm{~N}$ (dois LEDs).

Cada medição foi iniciada automaticamente quando a sonda foi colocada em contacto directo com a pele e em posição perpendicular à superfície da pele com uma pressão constante durante poucos segundos. Para cada participante foram feitas três medições consecutivas e calculada a média dos valores obtidos. A hidratação superficial foi quantificada no tempoT0, T1 eT2.

\section{MoistureMeterD®}

O MoistureMeterD ${ }^{\circledR}$ (Delfin Technologies Ltd., Kuopio, Finlândia) foi utilizado para medir a hidratação profunda da pele. Este aparelho é constituído por uma unidade de medição e por diferentes sondas, que são seleccionadas em função da profundidade de medição pretendida $(0,5-5 \mathrm{~mm})$. $\mathrm{O}$ aparelho gera uma frequência de $300 \mathrm{MHz}$, enviando uma onda electromagnética de baixa potencia para a sonda coaxial e, consequentemente para a pele. A onda electromagnética reflectida é registada, correspondendo a leitura obtida à constante dieléctrica, sendo esta directamente proporcional ao conteúdo hídrico do tecido medido. A sonda utilizada foi a de $55 \mathrm{~mm}$, que permite medir a quantidade de água ao nível da derme a uma profundidade de $5 \mathrm{~mm}$

Cada medição foi iniciada, automaticamente, quando a sonda foi colocada em posição perpendicular e em contacto directo com a superfície da pele com uma pressão constante em poucos segundos. Para cada participante foram efectuadas três medições consecutivas e avaliadas em T0, T1 eT2. O dispositivo mostra directamente na ecrã os valores medidos. 


\section{Blood pressure}

During the study the blood pressure value was monitored with sphygmomanometer Tensoval Mobil Hartmann ${ }^{\circledR}$.

All results were analyzed by the SPSS 20.0. Univaried descriptive statistics were applied including a calculation of frequencies, measures of central tendency and dispersion. Hypothesis tests included the Shapiro-Wilk test to verify the normality of the variables, and the Pearson correlation analysis to verify the existence of statistically significant differences. A 95\% confidence level was adopted.

\section{Results}

Monitoring of blood pressure during the study demonstrates that there are no variations in the two groups, as a result of experimental methodology (Table 2).

\section{Pressão arterial}

Durante o estudo o valor da Pressão arterial foi monitorizado com o esfignomanometro sistema Tensoval Mobil Hartmann $\AA$.

Os resultados foram tratados em SPSS 20.0, tendo sido realizada uma estatística descritiva uni variada com cálculo de frequências, medidas de tendência central e de dispersão. Foram ainda aplicados testes de hipótese de Shapiro-Wilk para verificar a normalidade das variáveis, e a correlação de Pearson com o objectivo de verificar a existência de uma relação estatisticamente significativas com um grau de confiança de $95 \%$.

\section{Resultados}

A monitorização da pressão arterial revelou a ausência de variações hemodinâmicas durante o estudo, em ambos os grupos, em função da metodologia experimental (Tabela 2).

Table 2 - Variation of blood pressure ( $\mathrm{mmHg}$ ) and heart rate (bpm)

Tabela 2 - Variação da pressão arterial $(\mathrm{mmHg})$ e frequência cardíaca (bpm)

\begin{tabular}{|c|c|c|c|c|c|c|c|c|c|}
\hline & \multicolumn{3}{|c|}{ Systolic / Sistólica } & \multicolumn{3}{|c|}{ Diastolic / Diastólica } & \multicolumn{3}{|c|}{ Heart rate / Frequência cardíaca } \\
\hline & T0 & T1 & T2 & T0 & T1 & $\mathrm{T2}$ & T0 & T1 & $\mathrm{T} 2$ \\
\hline $\begin{array}{l}\text { Group 1 } \\
\text { Grupo/ }\end{array}$ & $113,33 \pm 10,75$ & $110,93 \pm 11,04$ & $110,87 \pm 10,09$ & $75,73 \pm 8,15$ & $75,8 \pm 7,18$ & $74,4 \pm 7,46$ & $68,93 \pm 9,35$ & $71,87 \pm 12,87$ & $71,20 \pm 10,62$ \\
\hline $\begin{array}{l}\text { Group 2 } \\
\text { Grupo/ }\end{array}$ & $111,00 \pm 9,19$ & $112,00 \pm 10,03$ & $110,88 \pm 5,59$ & $75,75 \pm 9,11$ & $71,25 \pm 6,86$ & $73,5 \pm 7,48$ & $70,00 \pm 8,62$ & $70,38 \pm 12,44$ & $67,75 \pm 10,58$ \\
\hline
\end{tabular}

The values of biometric variables and BMI value obtained in the two groups (Table 3) revealed no significant differences in the values of BMI, TBW, ECW, ICW for both groups, as shown in Figure 2 for Group 1 and figure 3 for Group 2. The results show that there were no changes in the distribution of water volume in the body which reflects the body's ability to maintain the fluid balance, whereby the results of the physiology of the skin can be directly connected with the dietary water supply.
Os valores das variáveis biométricas e o valor do IMC obtidos nos dois grupos (Tabela 3 ) demonstram que não existem diferenças estatisticamente significativas dos valores do IMC, TBW, ECW, ICW para os grupos, como se pode observar na figura 2 para o Grupo 1 e figura 3 para o Grupo 2. Os resultados indicam que não se observaram alterações no volume de distribuição da água no organismo mantendo-se o normal balanço hídrico, pelo que, os resultados sobre a fisiologia da pele podem ser directamente relacionados com o aporte dietário de água.

\begin{tabular}{c|c|c|c|c}
\hline \multirow{2}{*}{} & \multicolumn{2}{|c|}{ GROUP 1 / GRUPO / - N=17 } & \multicolumn{2}{c}{ GROUP 2 / GRUPO - N=8 } \\
\cline { 2 - 5 } & T0 & T2 & T0 & T2 \\
\hline \multirow{2}{*}{ IMC } & $21,99 \pm 2,87$ & $22,25 \pm 2,97$ & $23,28 \pm 1,53$ & $23,27 \pm 1,51$ \\
\hline TBW & $30,98 \pm 2,68$ & $31,27 \pm 2,74$ & $35,02 \pm 2,34$ & $34,56 \pm 4,59$ \\
\hline ECW & $14,52 \pm 1,25$ & $15,24 \pm 2,97$ & $16,84 \pm 2,98$ & $15,86 \pm 4,52$ \\
\hline ICW & $16,07 \pm 1,91$ & $16,15 \pm 2,17$ & $16,68 \pm 3,15$ & $17,86 \pm 1,81$ \\
\hline
\end{tabular}

Table 3 - Descriptive analysis of volunteer's Body Mass Index (BMI), Intra-cellular water (ICW), Extra-cellular water (ECW) and Total body water (TBW) are only displayed in litres (LT) as a unit of measure.

Tabela 3 - Análise descritiva dos voluntários Indice Massa Corporal (IMC), Água intra-celular (ICW), Água extra-celular (ECW) e Água total (TBW) medidos em litros. 


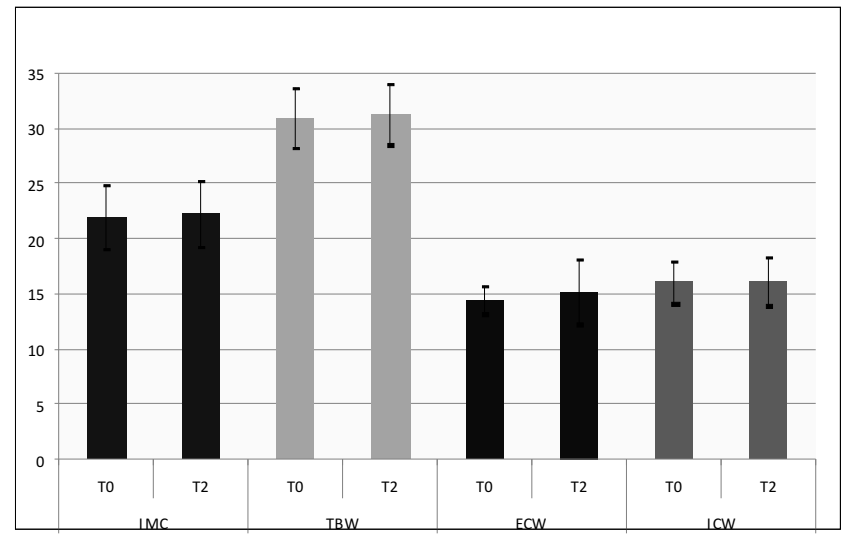

Figure 2 - Group $1 \mid$ Biometric variables and distribution of water in the body $(\mathrm{p}>0,05)$.

Figura 2 - Grupo 1 | Variáveis biométricas e distribuição da água no organismo

In this sense (Table 4), a statistically significant increase of skin hydration on the face (forehead and zygomatic) and forearm was observed in group $1 \mathrm{in} T 1$ and in the T2. In the hand, a significant increase was detected at the end of the study (T1 vs. T2). No statistically significant differences were detected in the leg. In group 2, a significant increase in hydration was noted in the face (figures 3 and 4).

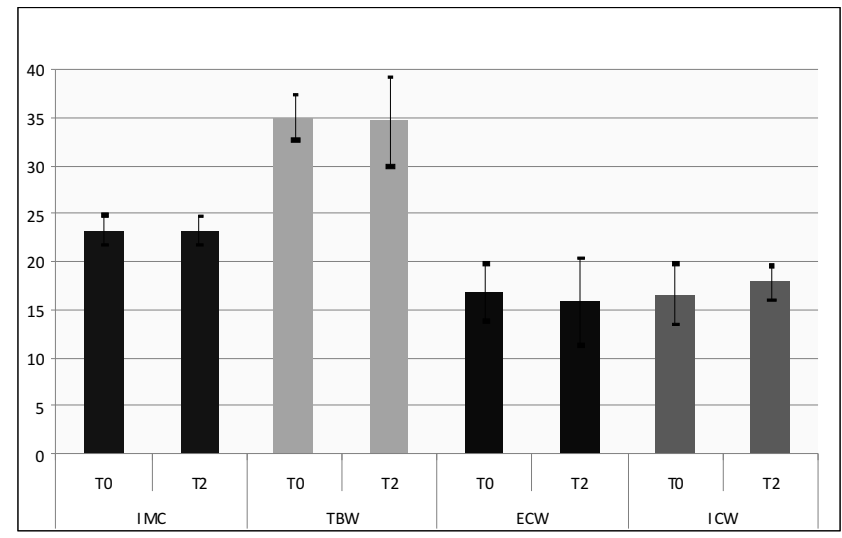

Figure 3 - Group 2 | Biometric variables and distribution of water in the body $(\mathrm{p}>0,05)$.

Figura 3 - Grupo 2 | Variáveis biométricas e distribuição da água no organismo

Neste aspecto (Tabela 4), podemos observar no grupo 1 um aumento estatisticamente significativo da hidratação da pele na face (fronte e zigomática), e antebraço observadas em T1 e no final do estudo (T2). Na mão o aumento é significativo no final do estudo (T2 vs T1). Na perna não há diferença estatisticamente significativa. No grupo 2 o incremento da hidratação é significativo na face. É também possível observar estas variações dos valores médios nas figuras 3 e 4 .

Table 4 - Superficial Hydration measure in Arbitrary Unit AU - MOISTUREMETER SC® $2 \mathrm{~mm}$.

Tabela 4 - Hidratação superficial, expressa em Unidades Arbitrárias UA - MOISTUREMETER SC $®$ $2 \mathrm{~mm}$

\begin{tabular}{|c|c|c|c|c|c|c|}
\hline & T0 & T1 & $\mathbf{T 2}$ & $\begin{array}{c}\text { P-Value } \\
\text { (T1 vs T0) }\end{array}$ & $\begin{array}{c}\text { P-Value } \\
\text { (T2 vs T1) }\end{array}$ & $\begin{array}{c}\text { P-Value } \\
\text { (T2 vs T0) }\end{array}$ \\
\hline \multicolumn{7}{|l|}{$\begin{array}{l}\text { Group / } \\
\text { Grupo } 1 \text { N=17 }\end{array}$} \\
\hline Fronte/Forehead & $66,55 \pm 22,81$ & $75,02 \pm 15,73$ & $81,18 \pm 10,53$ & 0,046 & 0,047 & 0,008 \\
\hline Zigomática/Cheek & $54,00 \pm 29,94$ & $73,11 \pm 19,97$ & $80,16 \pm 16,79$ & 0,004 & 0,179 & 0,000 \\
\hline Mão/Hand & $40,17 \pm 20,37$ & $47,58 \pm 18,64$ & $52,61 \pm 18,32$ & 0,136 & 0,202 & 0,005 \\
\hline Antebraço/Forearm & $33,49 \pm 10,70$ & $41,29 \pm 14,38$ & $43,33 \pm 13,29$ & 0,025 & 0,461 & 0,004 \\
\hline Perna/Leg & $42,67 \pm 21,30$ & $50,16 \pm 14,71$ & $52,47 \pm 17,26$ & 0,158 & 0,479 & 0,061 \\
\hline \multicolumn{7}{|l|}{$\begin{array}{l}\text { Grupo/Group } 2 \\
\mathrm{~N}=8\end{array}$} \\
\hline Fronte/Forehead & $61,33 \pm 18,14$ & $62,21 \pm 15,19$ & $80,29 \pm 16,39$ & 0,899 & 0,002 & 0,048 \\
\hline Zigomática/Cheek & $63,04 \pm 24,68$ & $62,97 \pm 19,14$ & $84,75 \pm 16,01$ & 0,995 & 0,007 & 0,117 \\
\hline Mão/Hand & $46,88 \pm 22,67$ & $48,03 \pm 12,34$ & $48,62 \pm 10,04$ & 0,916 & 0,920 & 0,844 \\
\hline Antebraço/Forearm & $45,54 \pm 18,56$ & $38,96 \pm 9,19$ & $36,37 \pm 11,89$ & 0,257 & 0,521 & 0,300 \\
\hline Perna/Leg & $44,59 \pm 19,65$ & $49,89 \pm 16,63$ & $44,87 \pm 14,36$ & 0,527 & 0,467 & 0,977 \\
\hline
\end{tabular}




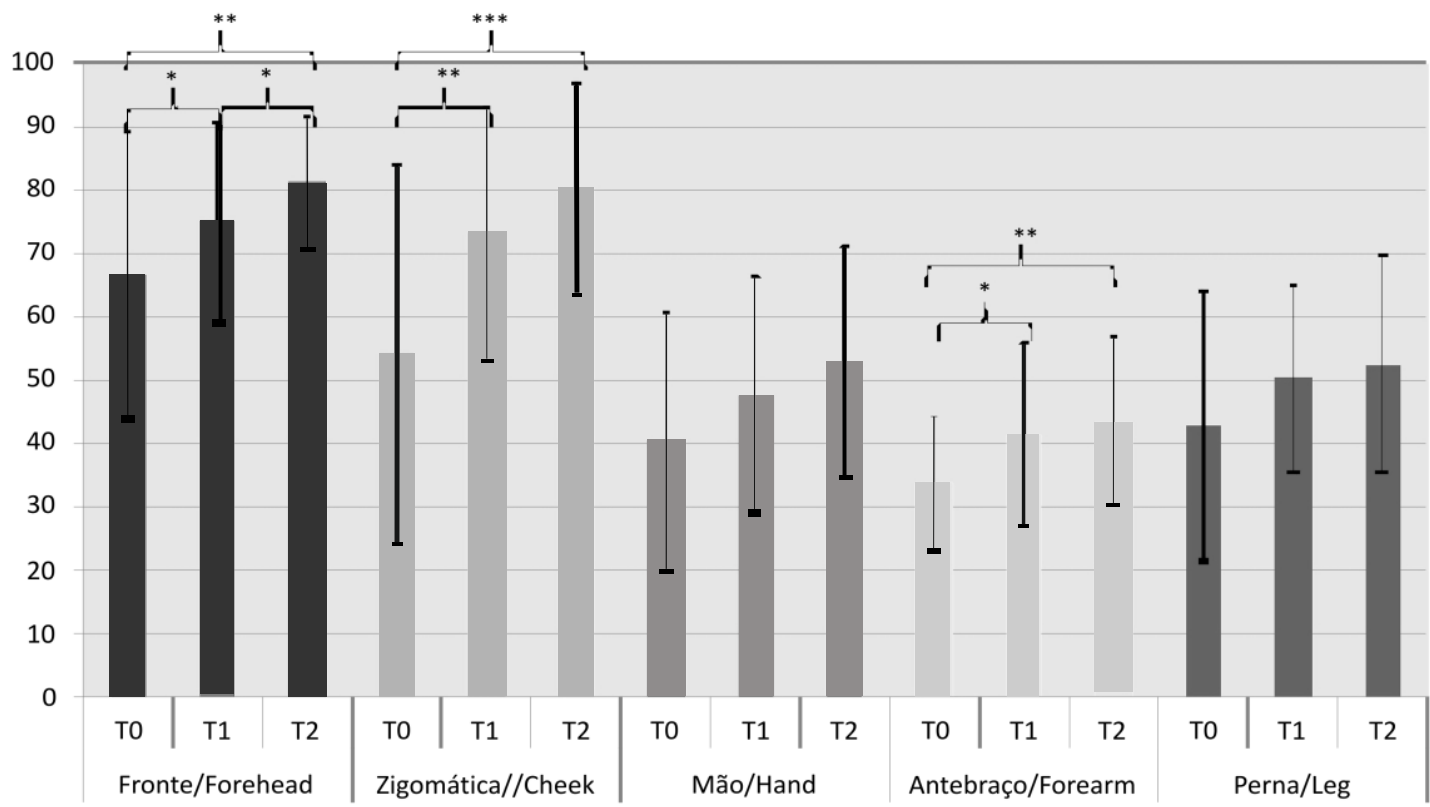

Figure 4 - Group $1 \mid$ Mean variations of superficial hydration during the study $(*: p<0,05 ; * *: p<0,01 ; * * *: p=0,000)$. Figura 4 - Grupo $1 \mid$ Variações médias da Hidratação superficial ao longo do estudo (*: $p<0,05 ;{ }^{* *}$ :p $<0,01$; $* * *: p=0,000)$.

The impact of water supply on deep hydration is summarized in Table 5 . The capacitance analysis shows that there is a statistically significant increase in deep hydration in group 1 in all the anatomical regions. For Group 2 variations are significant in the face (forehead and zygomatic). Figures 5 and 6 show variations in deep skin hydration during the study for both groups.
O impacto do aporte de agua na hidratação profunda está resumido na Tabela 5. A análise dos valores da capacitância demonstra que existe um aumento estatisticamente significativo na hidratação profunda para o Grupo $1 \mathrm{em}$ todas as zonas anatómicas. Para o Grupo 2 as variações são significativas na face (fronte e zigomática). As figuras 5 e 6 mostram a variação da hidratação profunda na pele ao longo do estudo respectivamente para o Grupo 1 e o Grupo2.

Table 5 - Deep hydration measure in Arbitrary Unit AU - MOISTUREMETER D ${ }^{8} 50 \mathrm{~mm}$.

Tabela 5 - Hidratação profunda expressa em Unidades Arbitrárias UA - MOISTUREMETER D ${ }^{5} 50 \mathrm{~mm}$

\begin{tabular}{|c|c|c|c|c|c|c|}
\hline Grupo/Group 1 N=17 & T0 & T1 & $\mathbf{T} 2$ & $\begin{array}{c}\text { P - Value } \\
\text { (T1 vs T0) }\end{array}$ & $\begin{array}{c}P \text { - Value } \\
\text { (T2 vs T1) }\end{array}$ & $\begin{array}{c}\text { P - Value } \\
\text { (T2 vs T0) }\end{array}$ \\
\hline Fronte/Forehead & smana & $45,38 \pm 11,19$ & $48,25 \pm 10,60$ & 0,002 & 0,030 & 0,000 \\
\hline Zigomática/Cheek & $28,78 \pm 5,27$ & $44,03 \pm 10,68$ & $46,27 \pm 9,74$ & 0,002 & 0,019 & 0,000 \\
\hline Mão/Hand & $35,25 \pm 5,38$ & $52,43 \pm 11,39$ & $55,07 \pm 10,97$ & 0,004 & 0,097 & 0,000 \\
\hline Antebraço/Forearm & $23,99 \pm 6,26$ & $36,87 \pm 11,12$ & $36,15 \pm 8,91$ & 0,002 & 0,053 & 0,001 \\
\hline Perna/Leg & $30,24 \pm 6,91$ & $48,16 \pm 12,95$ & $48,45 \pm 8,43$ & 0,001 & 0,401 & 0,000 \\
\hline \multicolumn{7}{|l|}{ Grupo/Group 2 N=8 } \\
\hline Fronte/Forehead & $22,21 \pm 7,04$ & $46,09 \pm 9,92$ & $51,45 \pm 3,94$ & 0,047 & 0,095 & 0,001 \\
\hline Zigomática/Cheek & $27,27 \pm 6,57$ & $46,79 \pm 10,81$ & $52,37 \pm 4,57$ & 0,162 & 0,145 & 0,000 \\
\hline Mão/Hand & $29,43 \pm 6,47$ & $52,56 \pm 14,04$ & $57,60 \pm 5,33$ & 0,209 & 0,231 & 0,001 \\
\hline Antebraço/Forearm & $20,37 \pm 4,65$ & $34,04 \pm 7,83$ & $39,93 \pm 6,74$ & 0,095 & 0,118 & 0,005 \\
\hline Perna/Leg & $26,95 \pm 5,49$ & $45,10 \pm 13,36$ & $51,76 \pm 8,07$ & 0,262 & 0,237 & 0,002 \\
\hline
\end{tabular}




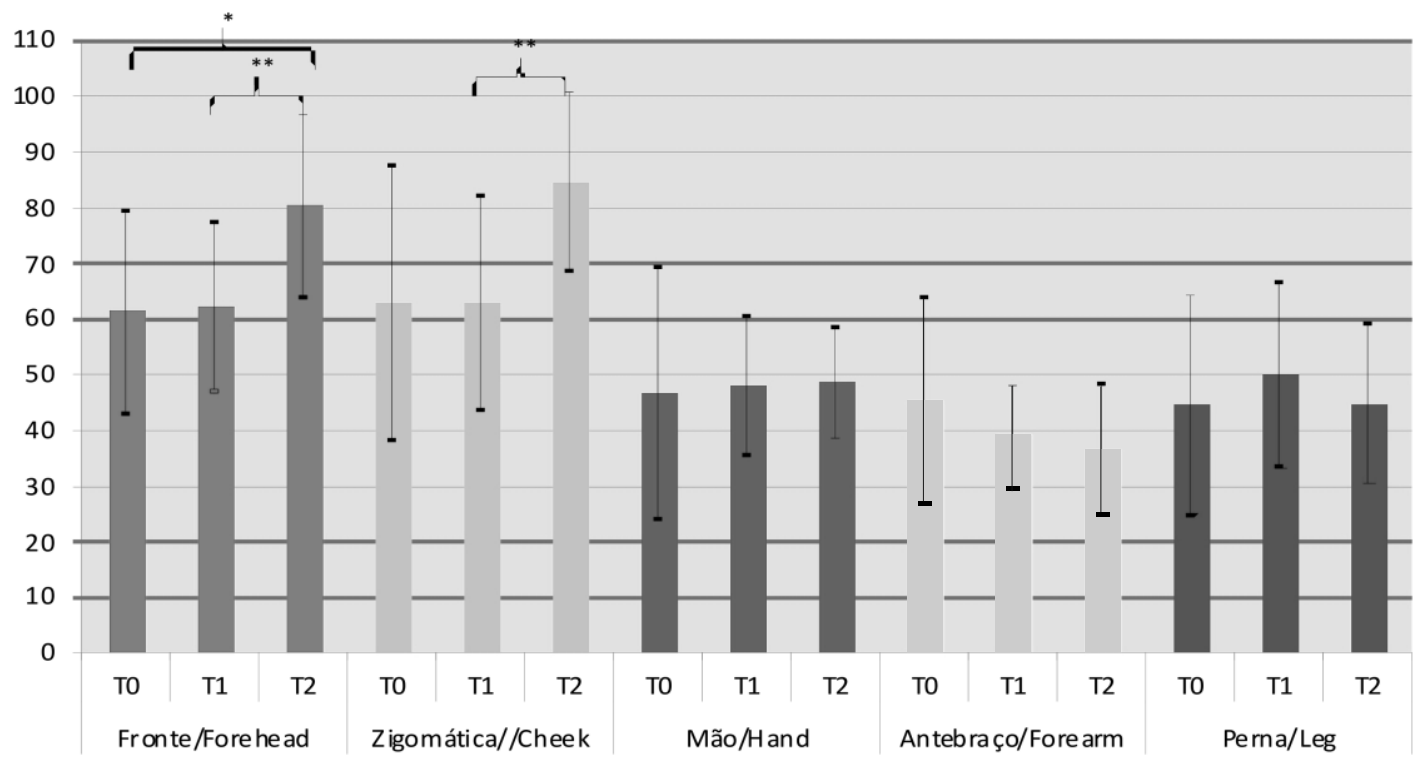

Figure 5 - Group $1 \mid$ Mean variations of deep hydration during the study $(*: p<0,05 ; * *: p<0,01 ; * * *: p=0,000)$.

Figura 5 - Grupo 1 | Variações médias da Hidratação profunda ao longo do estudo $\quad{ }^{*}: p<0,05$; $* *: p<0,01 ; * * *: p=0,000)$.

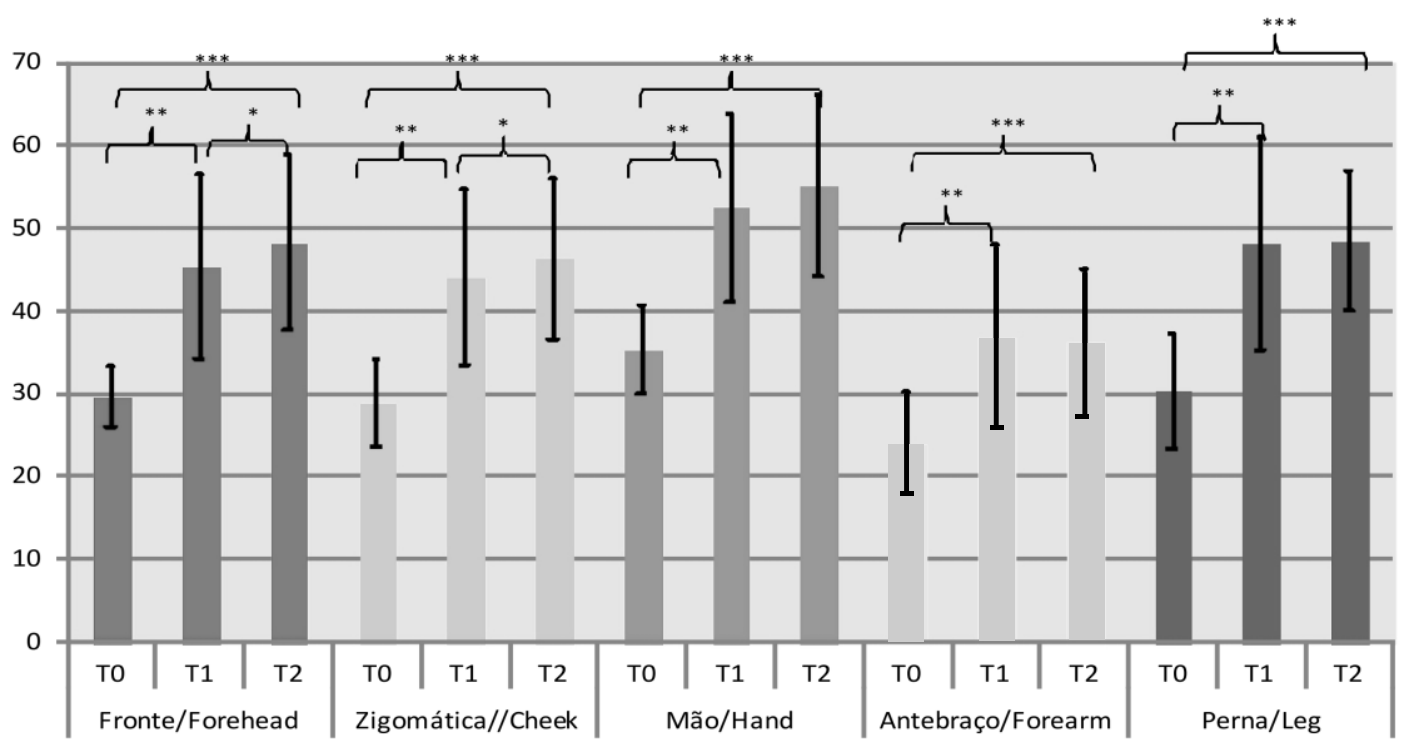

Figure 6 - Group $2 \mid$ Mean variations of deep hydration during the study $\left({ }^{*} p<0,05 ; * * p<0,01 ; * * p=0,000\right)$.

Figura 6 - Grupo 2 | Variações médias da Hidratação profunda ao longo do estudo $\left({ }^{*} \mathrm{p}<0,05\right.$; $\left.*^{* *}<0,01 ; * * \mathrm{p}=0,000\right)$.

The positive impact of increased skin hydration especially in individuals whose total intake of water is lower, suggests an improvement in skin hydration, as already reported in previous studies ${ }^{[19]}$. The lower magnitude of the effect in the forehead and cheek probably results from these being exposed areas which are regularly treated (cosmetics). Results also show positive changes in deep hydration, which suggests
O impacto positivo na hidratação da pele especialmente nos indivíduos cujo aporte total de agua é menor foi já sugerido em estudos ${ }^{[19]}$ anteriores. A menor magnitude da alteração registada na fronte e na região zigomática deve-se, provavelmente, ao facto de, se tratarem de áreas mais expostas e alvo de cuidados complementares diários. Os resultados relativos registados na hidratação profunda, reforçam a ideia 
an improvement in skin functions. Throughout the study, TEWL mean values of (Table 6) were statistically significant in the zygomatic, in the forearm and leg areas for group 1 and the forehead and leg for group 2, suggesting a moderate improvement in anatomical areas which are usually the driest. Figures 7 and 8 shows TEWL changes in both groups during the study. These changes suggest that a significant increase in the amount of water has little influence on the epidermal barrier function. de uma melhoria generalizada nas funções da pele. Ao longo do estudo as diferenças dos valores da PTEA (Tabela 6) revelaram-se significativas na região zigomática, no antebraço e na perna para o grupol e na fronte e perna para o grupo 2, sugerindo um ligeiro aumento nas áreas anatómicas que geralmente são mais secas. As figuras 7 e 8 mostram as variações dos valores do PTEA encontradas no grupo 1 e no grupo 2 ao longo do estudo. Estas alterações sugerem que o aumento do aporte da agua, nestas condições, pouco influencia a função barreira da pele.

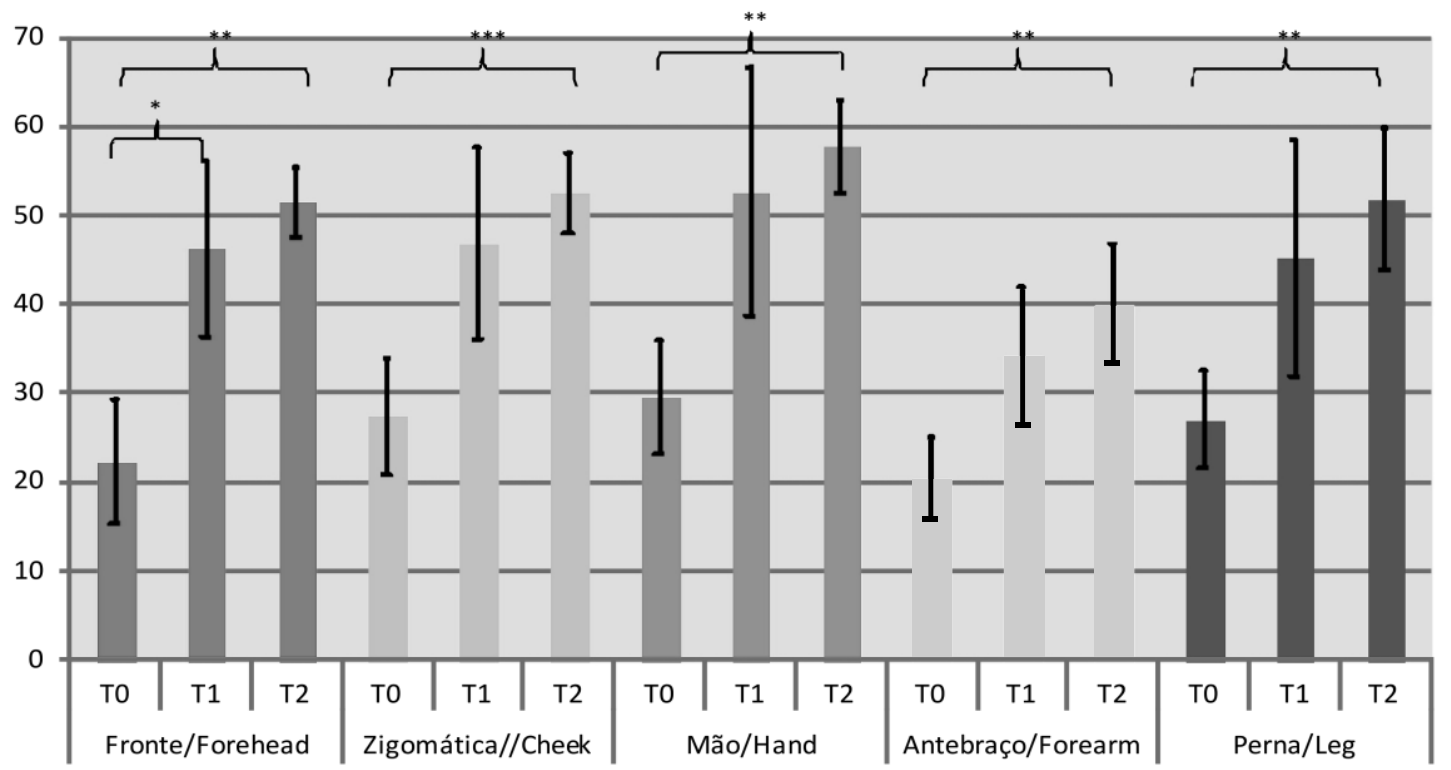

Figure 7 - Group1 | Mean variations of transepidermal water loss during the study $\left({ }^{*} \mathrm{p}<0,05 ;{ }^{*} \mathrm{p}<0,01\right)$.

Figura 7 - Grupo1 | Variações médias da Perda trans-epidérmica da água ao longo do estudo $\left({ }^{*} \mathrm{p}<0,05 ;{ }^{* *} \mathrm{p}<0,01\right)$.

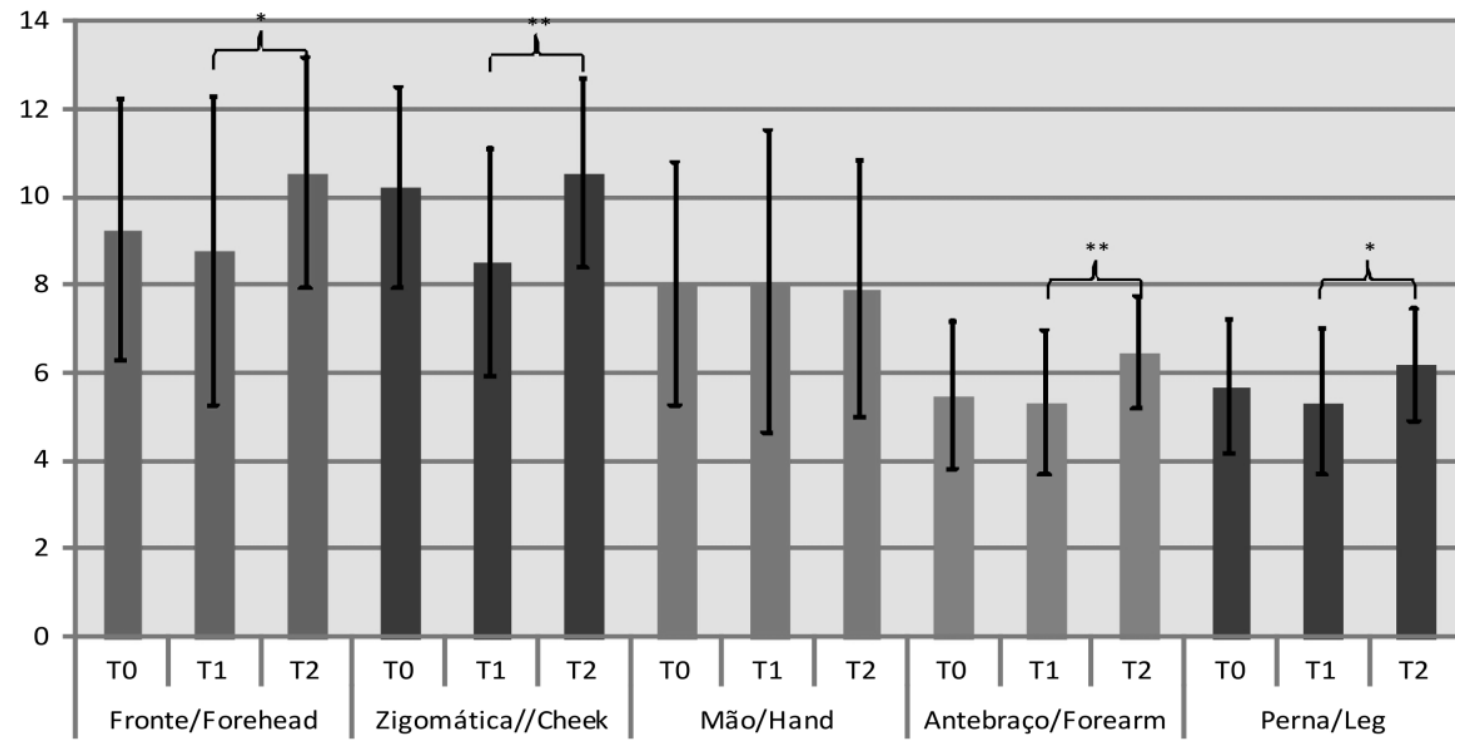

Figure 8 - Group $2 \mid$ Mean variations of transepidermal water loss during the study $\left({ }^{*} p<0,05\right)$.

Figure 8 - Grupo 2 | Variações médias da Perda trans-epidérmica da água ao longo do estudo $\left({ }^{*} p<0,05\right)$. 


\section{Conclusions}

These results show a clear relationship between increased water intake and skin hydration. The magnitude of the impact is much more evident in those individuals who regularly consume less water. Thus, in the absence of any haemodinamical changes, water from the diet seems to be a major component of skin physiology.

\section{Acknowledgements}

to Professor Carla Maria Lopes de Moura, from the University of Porto, to all participating volunteers, the Pharmacy Guardiano (Marinha Grande) owner of the Bodystat QuadScan ( ${ }^{\circledR} 4000$ and to UNICER that kindly offered the mineral water Vitalis . To all the authors, thank you for all the cooperation received .

\section{Conclusões}

Estes resultados evidenciam uma clara relação entre o aumento do aporte dietário da agua e a hidratação da pele. A magnitude deste impacto é maior nos indivíduos que consumem regularmente menos água. Assim sendo, podemos assumir que, na ausência de alterações hemodinâmicas, a água da dieta parece ser um componente principal da fisiologia da pele.

\section{Agradecimentos}

A Professora Carla Maria Lopes de Moura, da Universidade do Porto, aos voluntários que participaram no estudo, à Farmácia Guardiano (Marinha Grande) pela cedência do equipamento Bodystat ${ }^{\circledR}$ QuadScan 4000 e à UNICER pela oferta da água engarrafada Vitalis. A todos os autores expressam o seu agradecimento.

\section{Conflito de Interesses}

Os autores declaram não existir qualquer relação pessoal ou financeira que possa ser entendida como representando um potencial conflito de interesses.
The authors declare that there is no financial or personal relationship that can be understood as representing a potential conflict of interest.
[1]. Lang F, Waldegger S Regulating cell volume. Am. Scientist. 1997; 85: 456-463.

[2]. Jéquier E, Constant F. Water as an essential nutrient: the physiological basis of hidration. European J Clinical Nutrition 2010; 64, 115-23.

[3]. Popkin B, Kristen E, Water, Hydration and Health. Nutr Rev 2010; 68(8): 439-458.

[4]. Mandi J Bossingham, Nadine S Carnell, and Wayne W Campbell. Warwe Balance, hydration status, and fat-free mass hydration in younger and older adults. Am J Clin Nutr $2005 ; 81$ : 1342-50.

[5]. Guyton \& Hall. Textbook of Medical Physiology. 10th edition. W B Saunders Company. 2000. Pag 270.

[6].http://www.plataformacontraaobesidade.dgs.pt// Presentation Layer/Roda_dos_alimentos.aspx?menuid= 245\&exmenuid $=113 \&$ SelMenuId $=245 \&$ SelMenuId $=309$, 29/05/2012.

[7]. Nicolaidis S. Physiology and thirst. In: Hydration Throughout life. Jonh Libbey Eurotext.1998; p.247.

[8]. Rawlings A V, Matts P J. Stratum corneum moisturization at the molecular level: an update in relation to the dry skin cycle. J Invest Dermatol, 2005: 124: 1099-1110.
[9]. Gopinathan K. Menon, Gary W. Cleary, Majella E. Lane. The structure and function of the stratum corneum. International Journal of Pharmaceutics,2012, 435, 3-9.

[10]. Palma M, Monteiro C, Bujan M, Rodrigues Monteiro. Water intake and it's relationship with the water content of the diet in a healthy population. Biomedical and Biopharmaceuthical Research 2011(8):261-271

[11]. WMA Declaration of Helsinki - Ethical Principles for Medical Research Involving Human Subjects. [cited 28 April 2013]. Available from: http://www.wma.net/en/30publications/10policies/b 3/17c.pdf

[12]. Council of Europe - ETS no. 164 - Convention for the Protection of Human Rights and Dignity of the Human Being with regard to the Application of Biology and Medicine: Convention on Human Rights and Biomedicine[cited 28 April 2013.] Available from: http://conventions.coe.int/Treaty/en/Treaties/Html/164.htm [13]. LOPES C, CABRAL S, BARROS H: QUESTIONÁRIOS DE FREQUÊNCIA ALIMENTAR EFEITOS DA EXTENSÃO DAS LISTAS DE ALIMENTOS NA CLASSIFICAÇÃO DOS INQUIRIDOS. ARQ MED 1994;8:291-4
[14]. Krause's. Alimentos, Nutrição e Dietoterapia, 12a ed. 2008, pag146

[15]. European Food Safety Authority (EFSA) Scientific Opinion on Dietary Reference Values for water EFSA Panel on Dietetic Products, Nutrition, and Allergies (NDA). EFSA Journal 2010;

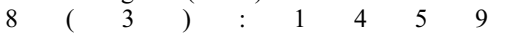
http://www.efsa.europa.eu/en/search/doc/1459.pdf $\underline{10 / 03 / 2013}$

[16]. ht t p://www.minsaude.pt/portal/ conteudos/enciclopedia+da+saude/obesidade/ comosediagnosticaaobesidade.htm(2012/11/08).

[17]. Bodystat. Bodystat ${ }^{\circledR}$ QuadScan 4000 Hardware User's Guide. Isle of Man:2007.

[18]. Courage+Khazaka electronic $\mathrm{GmbH}, 2003$, Information and Operating Instruction for the Tewameter ${ }^{\circledR}$ TM 300 Stand-alone and with software.

[19]. S. Mac-Mary, P.Creidi, D. Marsaut, C. Courderot-Masuyer, V. Cochet, T. Gharbi, D. Guidicelli-Arranz, F. Tondu and P.Humbert. [19]. Assessment of effects of an additional dietary natural mineral water uptake on skin hydration in healthy subjects by dynamic barrier function measurements and clining. Skin Research and Technology,2006 12, 


\title{
Impacto do excesso de peso sobre a fisiologia normal da pele humana in vivo
}

\author{
Liliana Tavares ${ }^{1}$, Lídia Palma ${ }^{1}$, Osvaldo Santos ${ }^{1}, M^{a}$ Angélica Almeida ${ }^{3}, M^{a}$ Julia Bujan $^{4}$ \\ \& L. Monteiro Rodrigues ${ }^{1,2}$ \\ ${ }^{1}$ Universidade Lusófona (CBIOS - Research Center for Health Science and Technologies), Campo Grande, 376, \\ 1749-024, Lisboa, Portugal \\ ${ }^{2}$ Dep. Pharmacological Sciences, Universidade de Lisboa - School of Pharmacy, Lisboa, Portugal \\ ${ }^{3}$ Serviço de Cirurgia Plástica e Reconstrutiva, HSJ-CHLC, Lisboa, Portugal \\ ${ }^{4}$ Universidade de Alcalá de Henares - School of Medicine, Madrid, Espanha \\ Email: f3872@ulp.pt; tavaresliliana@sapo.pt
}

\begin{abstract}
Obesity is an increasing public health issue, particularly in Portugal, where more than $50 \%$ of the population is obese. The pathophysiological consequences of being overweight have a severe cutaneous impact. However, there is still a lack of studies to link these alterations to BMI categories. This present work intends to identify the hydration and biomechanical behaviour changes related to weight augmentation. This transversal study was performed on a convenience sample of 57 volunteers, all females, aged between 20 and 46 (30 \pm 8$)$ years old. Volunteers were divided in two groups - group I, with a BMI between 19,9 and $24,9 \mathrm{Kg} / \mathrm{m} 2$ and group II, between 25 and $29,9 \mathrm{Kg} / \mathrm{m} 2$. One single determination of the superficial hydration, transepidermal water loss and biomechanical behaviour of the skin, was obtained with non-invasive methods. The data showed that weight increase positively influences hydration levels and transepidermal water loss, and negatively influences the skin's biomechanical behaviour. Despite the relevance of these results, there is still a need for complementary studies, with a wider number of individuals, in order to better understand its nature and meaning.
\end{abstract}

Keywords: overweight; BMI; skin hydration; TEWL; elasticity.

\begin{abstract}
Resumo
A obesidade é um problema de saúde pública com prevalência crescente, nomeadamente em Portugal, onde mais de $50 \%$ da população é obesa. As consequências fisiopatológicas do peso excessivo têm grande impacto a nível cutâneo. Contudo, existem ainda poucos estudos sobre a fisiologia cutânea, não existindo qualquer estratificação destas alterações em função do peso corporal. O presente estudo pretende contribuir para o estudo das alterações ao nível da hidratação e comportamento biomecânico com o aumento de peso. Este estudo transversal foi efetuado numa amostra de conveniência de 57 voluntárias, do sexo feminino, com idades compreendidas entre os 20 e os 46

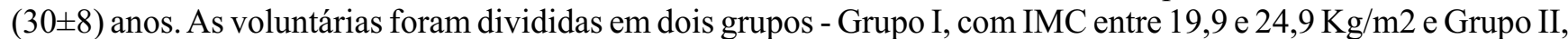
entre 25 e $29,9 \mathrm{Kg} / \mathrm{m} 2$. Foi efetuada uma única determinação da hidratação superficial, perda transepidérmica de água e comportamento biomecânico da pele (métodos não-invasivos). Os dados obtidos permitem-nos verificar que o aumento de peso influencia positivamente os níveis de hidratação e perda transepidérmica de água e de forma negativa o comportamento biomecânico da pele. Apesar do interesse destes resultados torna-se necessário realizar mais estudos, com maior número de indivíduos, de forma melhor esclarecer a sua natureza e significado.
\end{abstract}

Palavras-chave: excesso de peso; IMC; hidratação cutânea, PTEA, elasticidade. 